\title{
Individuaalsed valikud ja sotsialiseerumine eluloojutustuste põhjal
}

Tiiu Jaago

Teesid: Artikli põhiküsimuseks on, mil määral tõlgendatakse oma elukäiku individuaalse valikuna ja mil määral ajaloolis-sotsiaalsest raamistikust tuleneva paratamatusena. Analüüsis toetutakse folkloristlikele käsitlustele traditsiooni püsimisest etteantuse ja individuaalse kogemuse põiminguna ning eluloo-uurimuslikele käsitlustele "autobiograafilise mina" kujunemisest. Allikaks on kolm lugu, mis saadeti ühendusele Eesti Elulood 2000. aastal. Üheks võrdlusaluseks on ajastukontekst kui etteantus. Jutustajad on sündinud 1950. aastatel. Nende lood raamistuvad nõukogude aja kahe perioodiga (majanduslikult keerulised 1950.-1960. ja majanduslikult stabiliseerunud 1970.-1980. aastad) ning eluga taasiseseisvunud Eestis. Individuaalset elukäiku ei kujunda aga mitte ainult ajasturaam: uue olukorraga kohanemisel ja sündmuste tõlgendamisel tuginetakse oluliselt lapsepõlves väljakujunenud väärtussüsteemile. Analüüsi teine lugudepaar keskendub individuaalsetele valikutele vägivallaolukorras. Ilmneb, et konflikt ei seisne mitte ainult sündmuses (vastuhakk või füüsilise vägivalla kannatamine), vaid ka selle tõlgenduses (füüsilise üleoleku saavutamine ei taga probleemide lahendamist). Tõlgenduslik aspekt toetub taas kultuurilisele etteantusele.

Märksõnad: elulugu, nõukogude aeg, pärimuslik ajalugu, sotsiaalsed normid

Elulugu on žanr, mis lubab jälgida individuaalseid valikuid teatud ajalooliskultuurilises raamis. Ühiskonna valikud ei moodustu individuaalsete valikute summast ega ka vastupidi - ühiskond ei määra vahetult ja ühemõtteliselt indiviidi valikuid. Kuid mis siis toimub ühiskonna ja indiviidi suhete tasandil? Vaatlen seda ajaloolis-kultuuriliselt kujunenud traditsioonide kontekstis. Ajaloolis-kultuuriline keskkond annab inimese loole raamid ja sisaldab hetkeolustikku, toetudes varasematest ajaloolis-kultuurilistest kihtidest moodustunud pinnasele, st oleviku ja mineviku koosmõjus kujunenud traditsioonile.

Järgnevas artiklis on vaadeldud kolme eluloo võrdluse abil küsimust, milline seos valitseb individuaalse ja kollektiivse valiku vahel. Käesoleva ana- 
lüüsi tuumlugu kirjeldab ühelt poolt Eesti ühiskonna nõukogude argipäeva ja teiselt poolt vägivaldset, tavamaailmast äralõigatud vanglakeskkonda. Võrdluslood on valitud vastavalt nii, et ühel juhul oli samalaadne argipäev, teisel juhul äärmuslik keskkond - vägivald nõukogude armees. Traditsiooni osa neis lugudes vaatlen normi ja normiteadlikkuse kaudu.

Põhiväiteks on, et inimese sotsialiseerumise alus moodustub lähisuhete kaudu lapsepõlvekodus.

\section{1. Ühiskonnas kehtivad normid, normiteadlikkus ja roll}

Normi (nii käitumises, arvamustes kui ka pärimustekstides, sh jutustustes) võib folkloristlikust vaatepunktist mõista etteantusena (vt nt Arukask 2000), mida kontrollitakse ühiskondlike sanktsioonide kaudu. Normiteadlikkus, s.o teadmised normidest ja sanktsioonidest võteteni, kuidas teadmisi väljendada, moodustab ühiskonna väärtustesüsteemi, mille eesmärgiks on säilitada tasakaal "oma" ja "võõra" vahel.

Kuidas avaneb normiteadlikkus pärimuses? Lauri Honko, käsitledes haldjakogemust sotsiaalpsühholoogilisest vaatepunktist, kasutab normide uurimise kontekstis rolli mõistet. Rolliks nimetatakse ühiskonnas teatud staatusega liituvat kultuuriskeemide kogumit, mis panevad ühiskonnaliikme käituma teatud olukorras teatud viisil, kusjuures see käitumine sisaldab ka oskusi end väljendada, s.o kõnelda oma kogemusest, viia see vastavusse üldiste teadmistega kuni kultuurispetsiifiliste tekstide (nt loitsud vms) valdamiseni (Honko 1980: 95). Eluloouurimise kontekstis avab Juri Lotman rolli mõiste järgnevalt:

Õigust biograafiale ei oma kaugeltki kõik antud ühiskonnas elavad inimesed. Iga kultuuritüüp loob oma "biograafiaga" ja "biograafiata inimeste" mudelid. Millised ühiskonna liikmed on nn biograafiaga ja millised on ilma, neid arusaamu hakkavadki kujundama sotsiaalsed rollid ühiskonnas. "Biograafiaga inimene" seostub valikutega, mis lähtuvad ühiskonnas kehtivatest nn "õige käitumise normidest” (Lotman 1991: 366, $370,385)$.

L. Honko käsitluse juurde tagasi tulles võib küsida, kuidas on võimalik haldjakogemus ehk olematute nähtuste empiiriline kogemine. Kogemus lähtub sellest, mida või keda kuuldi või nähti, teadmised aga omandatakse ühiskondlikus suhtlemises (vt lähemalt Honko 1980). Suhtlemine ühiskonnas ongi folkloristlikust vaatepunktist jälgitav ja kirjeldatav etteantuse ja loominguli- 
suse koostoimimisena. Kogemusi tõsielu üksikjuhtumeist vahendatakse tõlgenduste kaudu: ei piisa ainult sündmuse läbielamisest (individuaalsest tasandist), vaja on ka tõlgendustasandit (rühmatasand). Läbielatu saab kogemuseks, kui sellele antakse tähendus, sealhulgas pideva jutustamise ja taasjutustamise käigus muutuvaid tähendusi. Üksikjuhtumite ja muutuvate tähenduste koostoimes luuakse järjepidevust (etteantust). Ühtlasi on selge, et etteantus ei ole konkreetsete juhtumite summa, vaid kogemuste najal loodud ja praktikas kasutuskõlblik kompass, mis folkloristikas tuleb esile mõistes "meie".

\section{Elulugude analüüs etteantuse ja individuaalse valiku vaatepunktist: teoreetilisi märkmeid ja allikaid}

Eluloojutustuse analüüsis saab tugineda "autobiograafilise mina" kujunemise uurimustele (vt BIOS), mis toetuvad Endel Tulvingu 1970. aastail alustatud episoodilise mälu uuringutele psühholoogias (Tulving 1994: 85). Selle järgi on oluline, et meeldejätmise olukord (taust, meeleolud jms) salvestub mällu koos faktidega ning tuleb omakorda nende faktide meenutamisel esile, kujundades seda, mida ja kuidas mäletatakse. Jutustuses on taust (meeleolud, valgused ja varjud) sündmuste ja olukordade kui faktide meenutamise kõrval lisainformatsioon, mida antud kontekstis (sotsiaalse mälu kujunemine) ei tasuks sündmuste uurimise varju jätta. Episoodiline mälu liitub seega pigem konkreetsete juhtumite kirjeldamisega (individuaalne tasand). Kuid sellele lisandub jutustamise käigus tähenduste andmine, nn etteantuse kontrollimine (rühmatasand).Viimane on aga pigem seotud semantilise mäluga (vt lähemalt Tulving 1994: 17-18, 85-104, 131, 139).

Avaliku ja privaatse suhet mõistan kui dialoogi inimese ja ühiskonna (üldsuse) vahel (vrd nt Jackson 2002: $14 \mathrm{jj}$ ): üldiselt arutlusel olevaid teemasid ja seisukohti arutatakse enesekeskselt, kuid samas püütakse omi vahetuid kogemusi ja arvamusi teistele avada. Selles kommunikatsiooniprotsessis kujunevad nii teadmised sellest, mida kogeti kui ka kogetule tähenduse andmised. ${ }^{1}$ Avaliku ja privaatse piirid ei saa olla kõikide teemade puhul universaalsed ega jaotada inimesi ja rühmi, teemasid ja nähtusi jäigalt joone taha nagu pallimängus. Pigem on piirid ettekujutatavad ja ehk n-ö kombatavadki.

Järjepidevuse kujunemist ühiskonnas aitab mõista üksiku ja üldise koostoime uurimine. Ühtlasi on see küsimus etteantuse ja loovuse seotusest. Üksikisiku valikud (oma elukäigu kujundamine) ja tema grupikuuluvusest tule- 
nevad võimalused (ühiskondlik-kultuurilised tingimused) ei ole kirjeldatavad pelgalt vastandlike tegurite koostoimena (vastandusega individuaalsed - üldised), vaid siingi eristuvad üldisemad (ajalooline, majanduslik, geograafiline jms) ja kitsamad raamid (nt vanemate soovid, harrastused, kodune igapäevaelu jms) (vrd Bertaux, Bertaux-Wiame 1991). ${ }^{2}$

Etteantus ja loomingulisus, "autobiograafilise mina" kujunemine suhtlemisprotsessis ning üksikisiku ja ühiskonna dialoog on järgneva käsitluse olulisemad märksõnad. Tõsielujutustused vahendavad objektiivse ja subjektiivse koosmõju, moodustades omaette tervikliku ja ainulaadse mäluuurimise allika, mis ei ole käsitletav pelgalt objektiivse või subjektiivse ainena.

Analüüsi tuumlugu esindab äärmuslikku elukäiku, eluks ajaks vangimõistetu lugu (EKLA f 350: 1347). Selle on jutustanud Eesti-Läti piiril 1951. aastal sündinud mees. Arvutikirjas kolmekümne seitsmele leheküljele mahtuv jutustus on saadetud elulugude kogumisvõistlusele 2001. aastal, kuid põhineb 1999. aastal tehtud intervjuul (jutustaja oli siis 48-aastane). Kirjaliku loo juurde kuuluvad pöördumine Eesti Vabariigi tolleaegse presidendi poole ja ümberkirjutus süüdistuskokkuvõttest. Kuigi ma ei tunne selle loo jutustamise ja kirjapanemise üksikasju, julgen väita, et see äärmuslik elukäik raamistub nõukogudeaegse argieluga (kui mees on vaba) ja sotsialiseerumise teemaga (kui vabaduse ja vanglaelu kogemuse ühtsuse kirjeldus).

Esimene võrdluslugu pärineb samast kogust (EKLA f 350: 967). Jutustaja on 1953. aastal Lõuna-Eesti külas sündinud naine, ametilt õpetaja. Et tema lapsepõlv möödus samas poliitilis-majanduslikus keskkonnas, kus dominantloo jutustaja oma, pakkus see pidepunkte lapsepõlve ja lähedaste suhete osast jutustaja elukäigu ja isiksuse kujunemisele. Teise võrdlusloo autor on ligi paarkümmend aastat noorem, 1970. aastal linnas sündinud mees, teadlane (EKLA f 350: 1338). Tema kasvuolustik ei haaku kuidagi eelnevate lugude jutustajate omaga. Lugu keskendub sotsiaalselt äärmusliku keskkonna kujutamisele, vahendades vägivallakogemust sõjaväes. See lugu haakub dominantlooga, et esile tuua isiksusest tulenev sotsiaalse käitumise valikute ruum.

Võib küsida, kas kolm lugu on piisav mingitegi järelduste tegemiseks. Küsimus ei ole lugude arvus, vaid nende valikus. Need kolm lugu on välja sõelutud üldisema eluloolugemuse taustal. ${ }^{3}$ Eluloojutustuste lausmaastikul eralduvad esmalt teatud teemad, seejärel kinnistub tähelepanu nende teemade variaablusele erinevates lugudes ja siis kujuneb vajadus täppisanalüüsi järele, mis on võimalik väheste, aga seda teemat eriti selgesti esile toovate lugude analüüsi abil. Järgnevad kolm alalõiku käsitlevad argielu ja isiksuse kujunemist, neljas alalõik vägivalda ja mina-pilti. 


\section{Kodu, eeskujud ja lähisuhted}

Esimene jutustaja alustab lugu ülevaatega oma perest 1950nadail ja 1960. aastate alguses: see viieliikmeline pere (ema, isa, kaks last ning vanaema) elas vaesuses ja riius. Isa töötas traktoristina, ema ja vanaema käisid põllutöödel, lapsed olid kodus. Ema ja vanaema sissetulekute kohta ei maini jutustaja midagi, isa kohta ütleb:

Palka ta suurt ei saanud. Aga ma mäletan, et kord aastas, tavaliselt aasta lõpus, tõi ta kodu palju vilja tööpäevade eest. See oli Ikla kolhoosi aeg. ${ }^{4}$

Millest siis elati? Loomi ka oli kodus. Sellega elati. Et normipäevade eest saadi vilja, selgub ka jutustaja kirjelduses isa töövälist, vabast ajast:

Isa tegi pidevalt puskarit, sest vilja oli küll. Aga ta ei müünud. Ta jõi koos oma endiste metsavendadega.

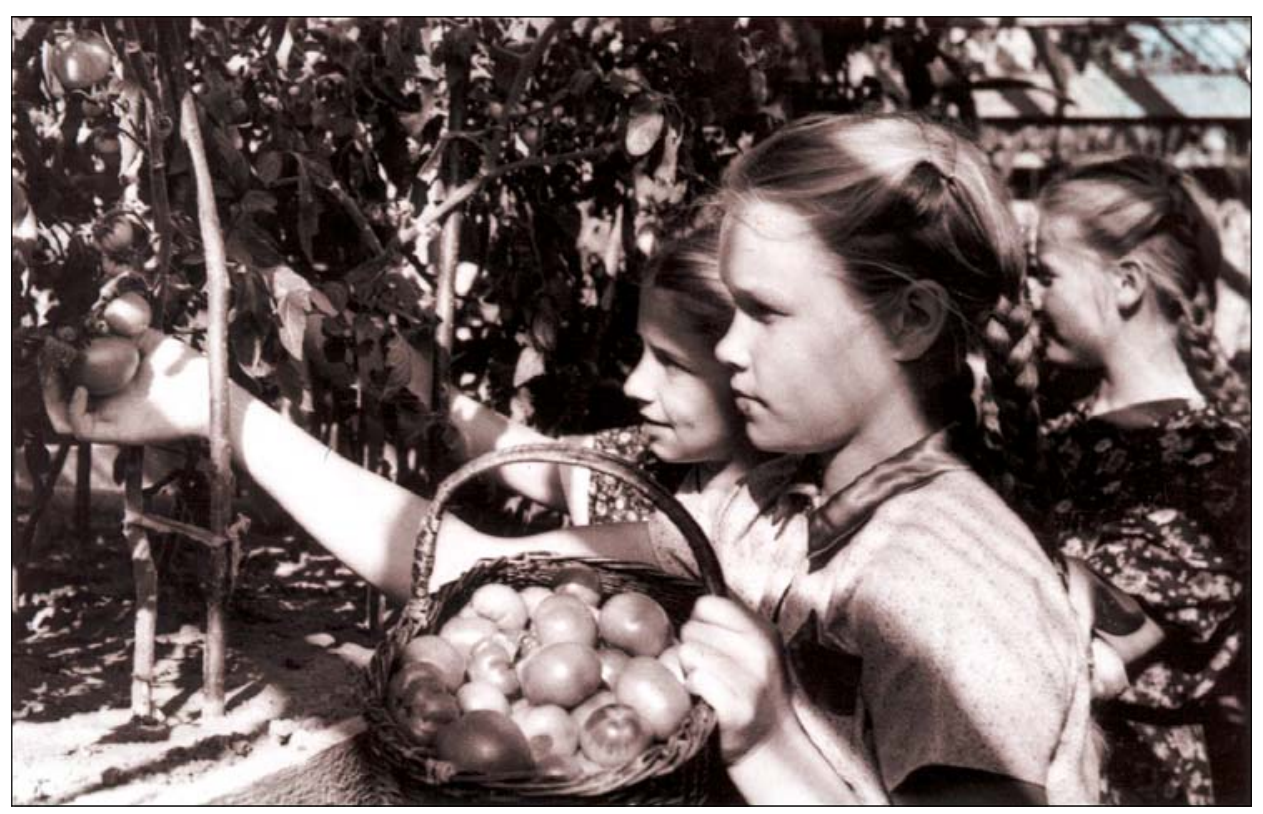

Foto 1. 1950. aastad ópilaste elus - kultuurilise järjepidevuse ja nõukogude ideoloogia risttee. Märjamaa keskkoolil on poolteise hektari suurune katseaed, kus õpilased kasvatasid maisi, tomateid, maapirni, söödakapsast jm. Peale selle oli sinna istutatud sada noort õunapuud. 1955. aasta kevadel lõpetasid 10. ja 11. klassi õpilased uue kasvuhoone ehitamise. Pildil: 8-b klassi ópilased (vasakult) Anna Vallikivi, Eda Kaldmaa ja Eha Kalda uues kasvuhoones tomateid koristamas. Z. Trelina (ETA) foto. 9. september 1955 (Läänemaa Muuseum HMF 61: 73). 
Sellega on antud veel üks ajaloo pidepunkt - isa kuulumine omaaegsete metsavendade hulka. See tõi 1950. aastatel, uutes poliitilistes oludes avalikkuse seisukohalt kaasa sotsiaalse marginaalsuse, mida omakorda tasakaalustab isa poliitiline vastasseis: ülemaid ja punaste pooldajaid ta ei sallinud. Peale sõpradega joomise mainib jutustaja isa tegevusest veel salaküttimist. Isa ja ema tülide põhjusena nähakse nende vaba aja veetmise erinevust: emale ei meeldinud, et isa joob.

Arvatavasti ka sellepärast tekkisid kodused tülid; ema aga tahtis käia igal pool ja läkski teiste naistega. Pahandused olid jälle majas.

Jutustaja lapsepõlve argielukorraldusest võib veel lugeda, et koduse majapidamise eest hoolitses vanaema: Ta oli nagu majandusülem perekonnas. Pere kokkusaamise aeg näikse olevat ühised söögiajad: Tavaliselt ôhtul olime koos lauas.

Jutustuse algusosa avab 1950. aastate ühiskonna Eesti ja Läti piirile jääva ühe koduelu kaudu: töötati ühismajandis, mis ei taganud elatist. Toidust siiski puudust ei tuntud:Liha, leib ja kartul olid alati kodus. Neid oli võimalik koduses majapidamises ise toota. Kõigega, mille muretsemiseks oli vaja raha, oli raskem:

Muidugi mingit head toitu meil polnud, nagu maiustusi ja nii edasi; muidugi riietus oli meil kehva võrreldes teistega.

Jutustaja avab väga napilt, aga selgelt olmesse puutuva: töö-ja tegevusalad, millest elatuti ja millega vabal ajal tegeldi, koduelu korralduse jms. Aga ta avab ka väljast antud hinnanguid (vihje sellele, et teised olid paremini riides) ning peresisestele tagasipeegeldustele tugineva pere- ja mina-pildi: ema selle kohta kogu aeg nurises isa kallal; isal oli ükskõik, kuidas ta oli; vanaema oli ka vähenõudlik; mina olin rahul kõigiga (kõigega?).

Mis jääb kõlama? Vaesus, riid, leplikkus, kõrvalejäämine ühiskonna keskteelt.

1953. aastal Lõuna-Eestis sündinud naine jutustab samuti tööst, magusapuudusest, noorte perede ebakindlusest ja vanavanemate olulisusest selles olustikus. Kuid tema mina-pilt on seotud tema perega, ta ei vastandu ega eraldu sellest, vastupidi, ta sulandub "meie" rühma:

Mind ümbritsevate inimeste elu oli sisustatud lõputu tööga. Vanavanemad ja ema käisid kuus päeva nädalas tööl. Pärast palgatööd ja pühapäeviti tehti kodutöid. Minu lapsepõlvekodus olid loomad [---]. Meil oli suur kartulipõld, kasvatati otra, palju köögivilja. Nii et kodutööd jätkus kõigile. Loomade talitamisega tegelesid vanaema ja ema, söögitegemisega vaarema ja vanaema, tubade koristamisega ema, vanaema ja vaarema, peenarde rohimise ja kastmisega jällegi vaarema, vanaema ja ema. 
Vanaisa kündis ja külvas, hoolitses mesilaste eest, tegi puutööd. [---] Hooajalistest töödest võttis alati osa kogu pere. Need tööd olid sõnnikuvedu, kartulite panek ja võtmine, heinategu, heinamaalt heinte kojuvedu, küttepuude lõikamine metsas [---]. Ka mina võtsin juba varajases lapsepõlves jõudumööda osa kõigist töödest. [---] Kuna nn riigitöö eest saadi väga vähe palka, siis tänu usinale tööle koduses majapidamises oli meie peres korralik toit laual ja viisakad riided seljas. Toidukraami osteti poest väga vähe - suhkrut, soola, mõnikord harva suitsukala, riisi ja minule kompvekke. Minu varases lapsepõlves küpsetati kodus veel ka leiba, pärastpoole toodi seda siiski poest.

Vaba aja täitmist esindab peamiselt raamatute lugemine, aga ka päevikupidamine, kinos käimine jms, lugu peeti laulmisest. Ajastu poolt ette antud raamid mõlemas loos on samad. Neisse raamidesse paigutuv isiku valikuist tulenev argielu aga täidetakse erinevalt.

Meesjutustaja ei maini peresuhetes lähedast kontakti oma ema ja õega. Õe suhtes on ta sageli vaenulik. Vanaemast peab ta ilmselt lugu, sest vanaema hoiab teda ja peret (Vanamutt aitas vanglakoti valmis panna, kui tulevad järel, siis on kohe kõik võtta, mida on vanglas vaja). Kuid jutustaja distantseerub temast. Sellist lähedust, nagu tal on isaga, ei paista aga vanaemaga olevat. (Võimalik, et selle taga on isa arusaam, kuidas mees peab suhtuma oma pere naissoo esindajatesse.) Isast kirjutabki ta ehk kõige soojemalt.

Naine esitab oma loo alguses lähedaste lühielulood. Seejärel suhtestab ta end nendega. Esialgu teeb ta seda väga pinnapealselt, nagu meeski. Ometi mainib ta midagi emotsionaalset: ta eeldab, et ta oli soovimatu laps. Kuid hoopis avaramalt näitab ta oma suhet lähedastesse alalõigus, mille ta pealkirjastab "Minu lapsepõlve vaimne elu" - seal väärtustab ta vanaisa laia silmaringi ja vanaema laulmist. See lubab tal teha lapsepõlvest kokkuvõtte: see on seotud heade mälestustega, inimesed, kelle keskel ta elas, olid kas tasakaalukad või närvilised, aga ikka põhiolemuselt head inimesed. Ta teeb kokkuvõtte:

Minul lapsena oli selles kodus hea olla. [---] Elati väikeste inimeste tagasihoidlikku elu ja anti mulle selle elu kaudu minu edaspidiseks eluks väga kindlad põhimõtted: minus kasvatati töökust, ausust, tõe- ja tarkusearmastust, armastust looduse ja lähedaste inimeste vastu.

Mees ei analüüsi, mida ta on lapsepõlvest saanud.

Kahe samasse aegruumi kuuluva loo võrdlemisel tuleb esile valikute kontrast just vaba aja veetmises ja sealt lähtuvas lapsepõlvekodu elukvaliteedis. Sellest joonistuvad välja ka peresuhted ja enda suhestamine oma koduga. Ometi hakkavad just need tegurid - elukvaliteet, suhted lähedastega - kandma jutustajate edaspidist käekäiku. 


\section{4. Ühiskonna tagasipeegeldusi ühe jutustaja loos}

Kool on esimene etapp, kus jutustajad tajusid ühiskonna tagasisidet oma päritolule ja vanematele. Meestegelane kirjeldab eemaletõugatust: nii tema õde kui ka ta ise käisid koolis Lätis: Eesti koolis öeldi, et nemad metsavenna lapsi ei õpeta. Kooliga seoses meenutab ta kogemust, millel on selles loos mõneti võtmetähendus: Mul õppimisega väga hästi ei läinud. Ma ei saanud kaasõpilastega hästi läbi. Nad mind narrisid, et olen metsavend ja fašist.

Seda olukorda võiks mõista piiril olemisena: ühel pool on kodu (privaatsfäär), teisel pool ühiskond (avalik sfäär). Üha selgemini ilmneb, et need vastanduvad. Kooliajast kirjeldab jutustaja talle vastanduvaid kaasõpilasi ja nende vanemaid. Täpsemalt ei kõnelda kooli juhtkonnast ega õpetajatest, kes teda isa mineviku pärast Eesti kooli ei lubanud. Umbisikulisest isikuliseks saavad need õpetajad, kes teda aitavad:

Oli üks pioneerijuhataja, kes mind kaitses ja tahtis õigust maksma panna, kuigi mina pioneer ei olnud. Lõpuks läks asi nii kaugele, et ta sai minu pärast kannatada. Olime tihti koos üksinda kooli punanurkas ja töökabinetis. Vahest öö läbi. Tegin igasuguseid plakate ja muud asju, mis koolil vaja oli. Algul kiideti, aga pärast kellegil see ei meeldinud. Läks jutt lahti, et mina olen õpetajaga seks vahekorras. Olin kolmeteistaastane.

Näib, et natuke võib siin olla ideoloogilise kasvatustöö varje (kooli punanurk, kus tehakse plakateid jms), aga see ei ole oluline. Esimene mulje on, et oli pioneerijuht suurepärane pedagoog, kes suutis tõrjutud lapsele rakendust leida, kuid põrkus kaasinimeste madala vaimutaseme vastu. Tuleb siiski tõdeda, et jutustaja üllatab lugejat millegi teistsugusega: Vahest koos ôhtuti puskarit küll võtsime, mis oli siirupiga magusaks tehtud, aga mitte purju.Üha enam kerkib lugeja ette küsimus, missuguses keskkonnas see poiss küll elas.

Naine kirjeldab ühelt poolt kooliks ettevalmistatust, teiselt poolt aga sotsiaalset ebakindlust:

Läksin kooli hea ettevalmistusega, aga hästi ma koolis end ei tundnud, sest maalapsena ei osanud ma omaealistega kontakti leida. Ma polnud tõrjutud, aga mul polnud esimestes klassides tõelisi sõpru.

Temagi loos on koolimälestuste ja õpetajatega seoses nii positiivseid kui ka negatiivseid toone.

Kui läksin viiendasse klassi, muutus mu koolielu huvitavamaks, vaimselt rikkamaks. Eeskätt sellepärast, et pääsesin esimesest õpetajast ja temaga seotud pingetest. Asemele tuli palju uusi õpetajaid, kes valdavas osas olid mulle sümpaatsed ja huvitavad. 


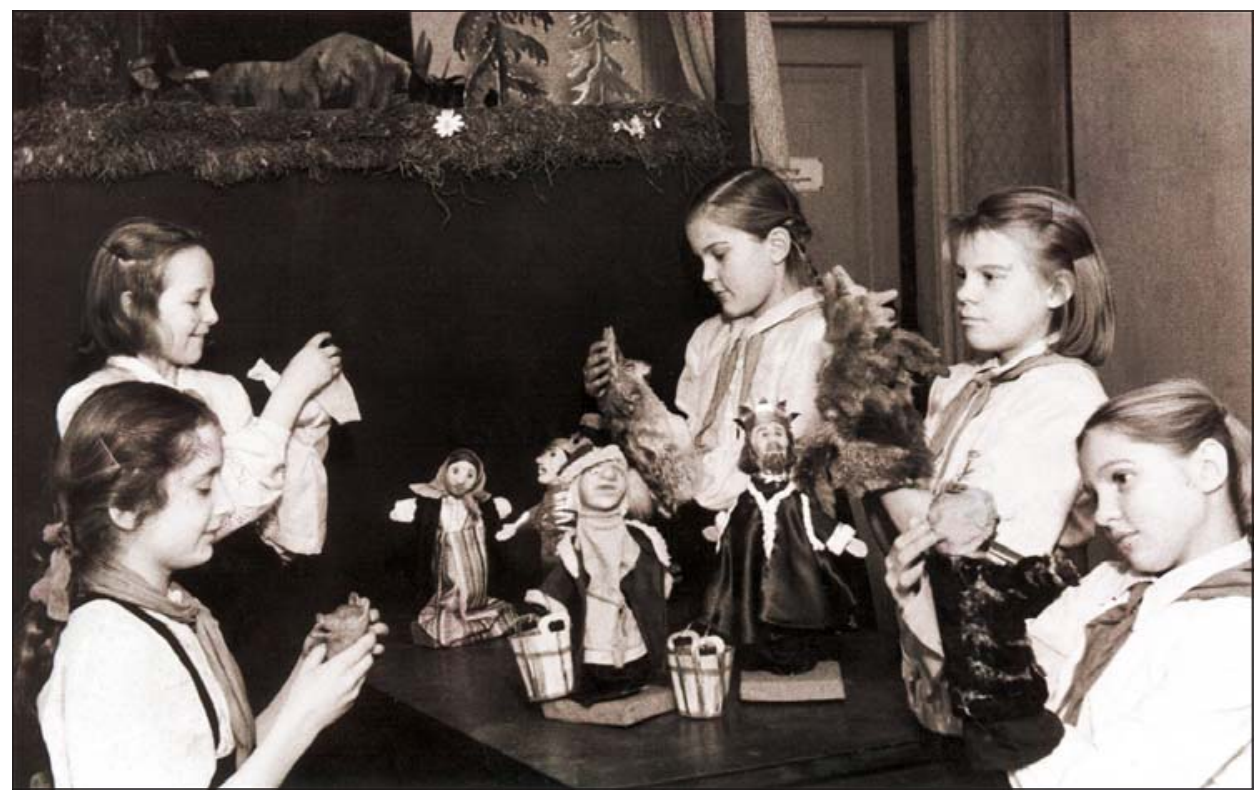

Foto 2. 1950. aastate ideoloogia järgi töötas hästi Haapsalu Pioneeride maja juures tegutsenud nukuteatriring. Ringi tööst võttis osa 35 pioneeri. Pildil valmistavad nukuteatriringi liikmed nukke nääripühade ajal ettekandele tuleva näidendi tarbeks. E. Järve (ETA) foto. 27. detsember 1952 (Lä̈̈nemaa Muuseum: HMF 61: 67).

Näib, et tütarlapse minek kooli vastandab teda tugevamini vanavanemate väärtussüsteemidega kui see ilmnes mehe loos. Neiu kirjeldab oma usku õpetajate sõnadesse

[---] meie ilusast riigist ja kommunistlikust tulevikust. Ma ei tea, mida ta [õpetaja] tegelikult mõtles, aga mind suutis ta kommunismiideaalidesse uskuma panna, samuti Jumalast eemale peletada (mu vaarema uskus Jumalat ja oli ka mulle oma usu lapsepõlves kaasa andnud).

Ta kirjeldab sedagi, et ta ema oli nõukogude ideoloogia mõju all. Mees mitte midagi niisugust ei väida, vastupidi: ta eitab ühemõtteliselt ja isegi vihaseguselt nõukogude korda, nagu nõukogude avalikkus on ära põlanud tema (nemad metsavenna lapsi ei õpeta). Samas on naine jutustamise ajal saavutanud oma toonaste mõtetega distantsi: olin aldis õilsatele ideedele, kuid mul ei olnud võimet taibata nende ideede tagamaid. Lõpetuseks proovib ta leida vanaisa vaatepunkti: Mida mõtles mu elukogenud ja tark vanaisa, seda pole ma saanudki teada. Nii kirjeldab ta pereliikmete erinevaid suhtumisi ja reageeringuid, mis õigupoolest on nüüdseks koondunud temasse ja kujunda- 
nud jutustajas uue lähenemisviisi nõukogude ajale. Mehe jutustuses, erinevalt naise omast, vaatepunkt ei muutu. Ta ei distantseeru varasematest valikutest ega mõtetest.

Edaspidisel eluperioodil on jutustajate argipäev ja selle sotsiaalne taust täiesti erinevad: mehe loos majandielu koos oma füüsiliselt raske töö, kuid suure palga ja kiitusegagi, naise loos majanduslik kitsikus ja vaimne töö. Nad sisenesid erinevasse sotsiaalsesse maailma, kuid nende kirjeldatud maailmad on sama ühiskonna erinevad poolused.

\section{Jutustamisaeg - oma loo mõtestamine}

Nii nagu mees ei distantseeru oma aruteludes varasematest seisukohtadest ega autoriteetidest, ei vaheta ta välja ka valikuid, kuigi ajastu tema ümber muutub. Ta varastab poest (sest süüa ei olnud ja pood oli nii hilja õhtul kinni) ja tapab (sest tekkis tüli). Ja ometi on tema kokkuvõte mina-pildi seisukohast: ma ei näe mingit õigust. Ta on ja jääb pahuksisse ümbritseva keskkonnaga. Saatus juhib mehe käekäiku ka 1990. aastate Eestis: tööpuudus, vaesus, ühiskonna korraldamatus:

Läksin ära Massiaru ühistu tööle lüpsjaks. [---] Aga laudas oli kõik lagunenud. Endal tuli kõik teha tasuta. Palka ei maksta 3-4 kuud, ela, kuidas tahad. Vahest, kui loomi tapeti, liha anti, piima ka, aga sellega ära ei ela. Läksin vabadel päevadel metsa tööle, et saaks raha natuke. Metsas teenis küll, aga ühistust ära minna ei saanud, siis oleks korterist välla visatud. Nälg oli majas, tee, mis tahad. Jah, need, kellel oli seal oma majapidamine, neil polnud häda midagi, kas saab raha kahe või kolme kuu pärast. Aga mul polnud kõrvalt kuskilt võtta. Tõstsin metsas selja ka ära, päris hädas. Sure nälga ära. Ööldi, et mingit haigusraha ei saa. Ja poleks saanud ka.

Naine kirjeldab poliitilise pöördeaja lootusrikkust, mis sumbus taas ebastabiilsusse ja lausa hirmu. Ta võrdleb elu nõukogude ajal eluga taasiseseisvunud Eestis:

Elu oli küllaltki stabiilne, ühiskonnas kehtivad reeglid olid pikka aega ühesugused, kõigile teada, inimesed tundsid ohte ja oskasid end hoida ja selletõttu oli inimestel olemas kindlustunne, ei olnud hirmu järgmise päeva ees.

Edasi kirjeldab ta võimalusi (ametikorterist tasuta kütte ja valgustuseni), kuid ei maini toonaseid olmemuresid ega troostitust, mis olid tema jutustuses va- 
rem. Naine, erinevalt mehest, on kummalises dialoogis iseenda mineviku ja olevikuga, eksleb ja otsib, on vastuoluline, kohati leplik, kohati pettunud. Miks just nii on läinud, põhjendab naine oma iseloomu, ebakindluse, elamisjõuetusega ühelt poolt, kuid ka ühiskondlik-poliitiliste oludega - õpetaja staatus ei olnud nõukogude ajal ega ole ka praegu tema meelest sotsiaalselt hinnatud. (Mees mäletatavasti asetas kõik temaga juhtunu põhjused endast välja: $M a$ ei näe mingit õigust).

Mõlema loo lõpus kordub selle algus: jõutakse tagasi vaesuse teemani (töö eest raha ei saa, ära elada oli võimalik vaid oma majapidamisest). Ilmneb, et ühiskondlik-poliitiliste pöörete järgsetel etappidel elatakse sellest pagasist, mis oli kaasa võtta varasemast ajast. Erinevalt oma vanematest (vanaemast?) mehel mingit majanduslikku toetuspinda eelnevast eluperioodist võtta ei olnud. Ei olnud võtta ka eetilis-moraalselt pinnalt. Otsus sünnib sellelt pinnalt, mis olemas oli: Läksin Massiaru poodi vargile. Ja jäin vahele. Sain poolteist aastat.

Sajandi lõpp ja uue aja algus tähendab ka naisele vaesust: ta selgitab, et kuigi ka Eesti NSV ajal elas ta majanduslikus mõttes tagasihoidlikult, ei tundnud ta siiski alaväärsust (mida ta praegu järelikult tunneb). Praegu ei taha ta unistada, plaane teha, lihtsalt kinnitab: Elame veel! Ometi saab ta taas, nagu lapsepõlveski, kirjeldada lähisuhteid (tagasihoidlikke, kuid argielu rütmistavaid koosviibimisi), pildi- ja perealbumeid, käike muuseumi, kunstinäitusele ja loodusse. Minu jaoks on mälestused elus väga tähtsal kohal ja ma tahan, et ka lapsel oleks mineviku meenutamiseks võimalikult palju pidepunkte, väidab ta.

Palju pidepunkte - see ongi võimalus arutleda, eksida, leida ja leppida. Mehe loos on nii mõtte- kui ka tegude valikuruum oluliselt kitsam.

Mõlemad jutustajad mõtestavad oma loo lapsepõlves omandatu kaudu. Endast saadakse teadlikuks esmalt pereliikmena lähedaste ringis, seejärel (kooliajal) asetatakse end ühiskonda, kus tavõetakse vastu pere taustal. Need seosed ja suhted hoiavad indiviidi oma "telje" (identiteedi) lähedal ka siis, kui ta näiliselt on saanud neist suhetest või etteantustest vabaks, iseseisvunud.

\section{Kes on olukorra peremees?}

Järgnevas lõigus vahetan võrdluslugu: tegevuspaik kandub äärmuslikku, tavaellu mittekuuluvasse keskkonda (vähemalt mõtteliselt või ideaalselt on see nii, reaalselt on ka siin kujutatu oma tasandil tavaelu). Kui eelmises võrdluses tuli esile keskkonna (lapsepõlv, kool, ühiskond) mõju isiku käitumisele, siis järgneva võrdluse teesiks on: keskkond ei määra vahetult ja ainsana individuaalseid valikuid. Need väited tunduvad vastuolulised, kuid just need tei- 
neteist täiendavad tahud peaksid selgitama, miks individuaalse valikuruumi kujunemisel on vajalik keskkondade paljusus, ja lõpuks, miks siiski näikse lapsepõlvekodu olevat määrav indiviidi valikuruumi suuruse (paljususe) kujunemisel.

Esmalt tuumloost. Mehest kujuneb jutukangelane, kes saab hakkama vanglas, kuid kes samade reeglite järgi elades ei saa hakkama vanglast väljaspool. Temast kujuneb vanglaelanik, kelle käitumine ja valikud ei toimi tavaühiskonnas. Järgnevalt kaks näidet, kus jutustaja peab end kriitilises olukorras kaitsma. Üks episood pärineb esimesest vangistusest aastal 1966:

Kambres oli 20 inimest. Päris kõik nad ühte ei hoidnud. Ma sain seda aru. Neil oli kolm neli tugevamat poissi kambres, kes kamandasid olukorda. Ma neid ei kartnud. Saatsin nad perse ja ütlesin, et nende järgi tegutsema ma ei hakka. Läks löömaks. Kambres oli teekann malmist, 5liitrine. Lõin pealuu kantpeal sisse. Teda viidi haiglasse. Mõni päev rahu. Keegi mind rohkem ei puutunud.

Ja teine, enam kui kolmkümmend aastat hilisem lugu 1998. aastast on pärit jutustaja kodust (elupaigast?) tema vabaduses olles:

Ärkasin, kui tuli põlema pandi. Till [jutustaja ema elukaaslane] seisis, nuga käes, ja ütles, et ma tapan su ära. Ma lõin nua käest valla. Ta taganes kööki, rabas puukasti pealt kirve. Mööda ma ei saanud. Haarasin sealt jahupüti pealt köiejupi. Viskasin talle külle pealt kaela ja tõmbasin kõvasti pingule. Kui kirves kukkus maha, lasin köie lahti. Till vajus põrandale ja ei liigutanud. Sain aru, et kägistasin ta ära.

Selliseid episoode on loos mitmeid. Kõikides neis on alati abivahend, mis ilmub lugeja ette kuidagi ootamatult. Nende asjade kohalolek ei ole võimatu (viieliitrine teekann vangikambris; köiejupp köögis jahupüti peal), kuid neid ei märkaks üldises asjade pildis. Jutustaja toob nad lugeja ette nagu muinasjutu imevahendid, mida ta kasutab sündmuste käigu muutmiseks. Abivahendite ilmumine kriitiliste olukordade kirjeldustesse on tunnuslik, nagu on iseloomulik seegi, et ta kirjeldab neid olukordi äärmiselt kokkusurutult. Mõned näited neist, kus rasvases kirjas olen esile toonud "abivahendid":

Riia vanglas. Läks löömaks, murdsin harjavarre pooleks ja lõin ühel autoriteedil soolikad segamini. Pandi mind kartsa ja teda haigla.

Viljandi koloonias. Mul taheti ka ära võtta valmistoodang. Ma ei andnud. Lõin viiliga jalasäärest läbi. Enam minuga tegemist ei tahetud teha. Pandi mind kartsa. Kantpea vanglasse. 
Tööl vasikalaudas. Üks suurem vasikas astus varvaste peale ja ei liigu paigast, tee mis tahad. Seal samas vasikaaia ääre peal oli paras haamer. Sain selle kätte, panin vasikal pähe.

Tjumeni vanglas. Haarasin laua pealt veekarahvini, panin talle pähä. Sain tappa. [---] Mul oli teritatud pliiats käepärast. Kohe küsiti, mis masti mees oled. Ma sõna lausumata panin kohe pliiatsiga makku neile. Seda nad ei oodanud. Sellega ma võitsin. Neid viidi haiglasse. Mind kartsa.

Näib, et asjade kulg ja neist kõnelemine toimuvad sama kiiresti. Hoopis teist taktikat kasutas vägivallaohus kolmas jutustaja, tookord noorsõdur:

Santšastis [sanitaarosakond] olles pü̈̈dsin suurest ahastusest veel päästa, mis päästa annab ja üritasin endale kõikvõimalikke haigusi külge valetada. Kurtsin küll pitsitust südames, küll astmat ja jumal teab, mida kõike veel, loomulikult polnud sel mingit mõtet.

Samuti kasutab ta ka teistsugust jutustamistehnikat: ta näitab vägivalda sõjaväes kui korduvat, lahendamatut järjekestvust, mitte lahendatust, nagu vangist jutustaja seda teeb. Noorsõduri pilgu läbi oli "vägivald roodus täiesti igapäevane":

Võin liialdamata kinnitada, et III roodus teenitud 8 kuu jooksul ei möödunud ühtegi päeva, mil ma poleks peksa saanud, tihti juhtus seda aga rohkem kui üks kord päevas. Alguses pü̈̈dsin vastu hakata, kuid õppisin üsna pea, et 5-6 vastu ei saa niikuinii ning vastuhakk muudab tagajärjed reeglina hirmsamaks.

Kogu jutustus ongi pigem vägivallakirjeldus kui sellele vastuhaku esitamine.

Peksti pidevalt ja kõikvõimalikel põhjustel, sageli selleks, et meelt lahutada. Tavaline päev oli selline: [---].

Kui tuumloo jutustaja kirjeldab vägivalda alati kui konfliktsituatsiooni ja selle lahendamist, siis selles loos on kujutatud vägivaldset keskkonda, millel ei ole põhjendust.

Lugedes sõdurijutustust, hakkas mind vaevama küsimus: miks ta seda teeb. Rutt Hinrikus, kes toimetas sama loo avaldamiseks kogumikus Eesti rahva elulood selgitas, et tema nägi selles tunnistaja vaadet. Minu jaoks teravnes küsimus selletõttu, et olin 1991. aastal Kohtla-Järvel välitöid tehes kõnelnud ühe 1960. aastail sündinud mehega, kes rääkis poliitilisest vägivallast (noormees oli seotud kooliõpilaste vastuhakuga poliitilistele jõududele 1980. aastal). Ta selgitas oma mälestusi psüühilisest vaatepunktist: inimene ei räägi 
tavaliselt temaga toime pandud vägivallast, sest ta ei talu nende meenutustega kaasnevat mälestust alandusest, allajäämisest. See on ehk seletatav episoodilise mälu eripäraga, millest eelnevalt oli juttu: fakti (sündmuse) meenutamisel rullub lahti ka selle meeldejäämise hetk (meelolud, aistingud jms). Vangi loos oleks nagu kõik korras: ta on oma loos vägivallaolukorras alati võitja. Sõduri loos on aga kõik vastupidine. Ka ei luba vangist jutustaja endale kellegi reetmist "mentidele" vms. See ei ole üldse probleem ega isegi mitte varjamist vajav seik sõduri loos (sõna otseses mõttes võtsin altkäemaksu ja valetasin selle eest kõrgele kohtule). Vastus peitub ilmselt sündmusele tähenduse andmises. Sõdur ei ole vägivalla ohver, erinevalt vangist, kes tunneb end lõppkokkuvõttes kaotajana?

Miks ei pea sõdur oma lugu kokku võtma sõnadega ma ei näe mingit ôigust, hakkab tasahaaval avanema märkustest, milles ta näeb vägivalla põhjendusi.

Ta ei olnud tegelikult halb inimene ja nagu öeldud, võinuks meist teistel asjaoludel isegi sõbrad saada. Pigem olid need asjaolud ning süsteemis valitsev kord, mis Elizbarist sellise elaja tegid.

Jutustaja tajub sõjaväekeskkonda kõrvalekaldena normaalsest. (Kogumikus Eesti rahva elulood ongi see lugu paigutatud alapealkirja "Suletud maailmas" alla.) Vangi loos on paraku just selline keskkond esil kui tavaline. Ka arutleb noorem jutustaja selle üle, et jõhkardiks muutumist põhjendati ise kogetud vägivallaga. Ta peab seda võimalikuks, kuid lisab: Kuigi huvitaval kombel ma enda juures selliseid arenguid hiljem ei täheldanud. See näikse olevat võtmetähendusega märkus: kellel on olemas individuaalsete valikute ruum, saab erinevates keskkondades hakkama. Selle loo telge tajusin mitte nii väga tunnistuses (see oli nii), vaid tõdemuses, et see keskkond ei kahjustanud jutustaja mina-pilti, mis ongi tema võit.

Ehkki sai kogetud hirmsaid asju, elasin ma need üle, fü̈silised haavad paranesid ja loodetavasti ei jätnud püsivaid jälgi ka psü̈̈hilised.

See periood oma elust muudeti kogemuseks, kuid olukorrast (nagu sõjaväestki) tuldi välja.

\section{Kokkuvõtteks}

Ajaloolis-poliitilinr raam esitatakse neis lugudes pigem etteantuse kui võimalusena. Nõukogude ajal ei saa mees minna Eesti kooli ega tööle riigipiiri taha merele, sest ta isa oli olnud metsavend. Naine kinnitab, et on teinud oma 
õpetajatööd ühiskonnas (nii nõukogude ajal kui ka taasiseseisvunud Eestis), kus seda ei hinnata. Noormees nõukogude sõjaväes sattus olukorda, millest ei olnud pääsu. Selle etteantusega ei vaielda, kuid sellele võidakse end vastandada (ei ole õigust siin ilmas), end lepitada (mul on siiski olnud võimalus teha meelepärast tööd) või nähakse võimalust sellest "raamist" loobuda (sõjaväekogemus). Siit joonistuvad välja valikud: mees teostab end raske füüsilise tööga, kaitseb end füüsilise jõuga ja saab hakkama. Naine "põgeneb" alternatiivsesse vaimumaailma ja tasakaalustub. Noormees analüüsib ja vaatleb end ja ühiskonda ning jõuab lahenduseni. Õigupoolest on kõik valinud töö, vaimse või füüsilise, et tunnetada ennast selles etteantuses kui keskkonnas. Kuid siingi ilmneb omakorda teatav etteantus: naine eelistanuks teadustööd, kuid tal ei õnnestunud seda saada - põhjuse leiab ta enda iseloomust, ebakindlusest. Mees pannakse teed valivas eas majandis ühele või teisele tööle, saadetakse kooli, teda kasutatakse ära - taas võib tema iseloom sattuda vastuollu nende valikutega. Noormees sõjaväes ei näe läbi kaaslaste kavatsusi ja kutsub sellega esile vägivalla enda vastu, mis on taas seostatav tema enda loomusega.

Elulugudes tuleb esile episoodilisele mälule tuginev kogemus normidest ja etteantusest, kuid ka oma valikute ruumi tunnetamine (isikuomadustest tulenevad piirid). Ilmneb ka, et etteantusest lähtuv valikuruum ei ole kõigile ühesugune, sest kõigile ühine ajaloolis-poliitilise raam ning kõigi erinev isikuomadustest tulenev raam on vanematest ja lähedastest mõjutatav.

Näib, et viimasel on võtmetähendus üldise ja üksiku tasandil valikute lõimumisel ja realiseerumisel. Näiteks naine, kes on saanud vanavanematelt usus Jumalasse ja kooliõpetajalt usu leninismi, saab lõppkokkuvõttes suurema valikuruumi kui mees, kellele anti kaasa vaid üks valik - eitada nõukogude korda. Ka mehe vanaema uskus Jumalasse, kuid see ei kandunud mehe maailma (jutustusse satub see teave ühe koerustüki kaudu). Jutustaja õde õppis muusikakoolis, kuid jutustaja pilgu läbi ei teinud õde tööd, vaid ja kääksutas ainult pilli. Ehk olnuks emalgi midagi pakkuda, kuid ainus eeskuju ja autoriteet oli isa - individuaalsete valikute ruum piirduski isa otsustega. Noormees, kes satub sõjaväes vägivalla keskpunkti, ei omanda seda käitumist normina. Miks, see jääb küll episoodilisele mälule tugineva kogemusjutustusena esitatud loost välja, kuid mitte kokkuvõte - loo tuumaks on jutustaja enese- ja ühiskonnaanalüüs. Vägivalda ei põhjustata põhimõttel, et temaga käituti halvasti ja ta vastab samaga. Jutustaja kogemus ütleb, et kuigi temaga käituti vägivaldselt, ei muutunud ta ise vägivaldseks. Tema valikuruumi vägivald normina kui etteantu ei imbu, tal on järelikult avaram individuaalne valikuruum. 


\section{Kommentaarid}

${ }^{1}$ Meenutatagu siinkohal Lauri Honko eelmainitud käsitlust haldjakogemusest - see võiks eriti esile tuua subjektiivsete ja objektiivsete tegurite koostoime üksikisikule teda ümbritsevas keskkonnas. Teadmise ja teadmatuse (tunnistamatuse) probleem võib ilmneda ka ajaloolise (mitte ainult üleloomuliku) kogemuse puhul. Näiteks Carol A. Kidron analüüsib psühholoogilisest aspektist holokausti üleelanute trauma ülekandumist nende laste põlvkonnale: kuidas toimib "mälu" traumaatilise minevikukogemusega teises põlvkonnas. Oma analüüsis, mida ta nimetab etnograafiliseks lähilugemiseks, ühendab ta trauma teraapiaga. Ilmneb, et trauma kui sotsiaalne kogemus on seotud sellega, mida ühiskond peab traumaks ja millised meetmed on ta trauma ületamiseks kehtestatud (Kidron 2003). Traumakogemuse ja teraapia vahelises "kõneluses", nagu Eestis näiteks küüditamise puhul, otsitakse oma mälestustele kohta avaliku ja isikliku vahelises ruumis, kuni jõutakse oma kogemuse asetamiseni mina-pilti. Selles avaliku ja isikliku dialoogis luuakse nn etteantust: nii, nagu "meil" õnnestub privaatne ja avalik hääl kõnelema panna, nii kujundatakse oma laste (järeltulijate) põlvkonna arusaama sellest, mis "meiega" toimus ja kuidas see on ka nende ajalugu. Nii saab kogemusest ja selle tõlgendusest meie-rühma identiteedi osa. Kui trauma ja teraapia ei ole avaliku ja privaatse vahel tasakaalu leidnud, võivad esile tulla ootamatused, nagu kogemused Teises maailmasõjas Saksa poolel sõdinute mälestusmärgi püstitamisel 20. ja 21. sajandi vahetusel, mis kutsus esile suuresti ka avalikku hukkamõistu. Õigupoolest on Eestis Teise maailmasõja ja nõukogude aja traumad teraapia seisukohalt alles läbi sõnastamata, sest poliitiliselt sunniti mälu vaikima. Sündmuste kogemisele on järgnenud sündmuste järelmõjud ja neist jutustamine.

2 Daniel Bertaux' ja Isabelle Bertaux-Wiame’i (1991) uurimus rajaneb sama suguvõsa mitme põlvkonna elukäikude vaatlusel. Küsimuseks on, millised tegurid individuaalseid elukäike kujundavad. Intervjuudest nopitakse välja nn empiirilised indikaatorid (kuidas jutustaja oma elukäigu juhtumeid seletab, milliseid põhjuslikke seoseid ta välja toob). Üldisemate põhjuste (sotsiaalne staatus, majanduslikud, geopoliitilised jms olud) kõrval tulid esile ka väiksemad tegurid (vanemate soovid, nende arvestamise määr jms).

${ }^{3}$ Sama teema ("Minu ja mu pere elu Eesti NSVs ja Eesti Vabariigis", 2000-2001) 320 loost olen läbi töötanud 85. Sama kogu (Eesti elulood) lugudest olen kokku konspekteerinud umbes 250 lugu. Kui aga juurde arvestada teiste arhiivide (Eesti Rahvaluule Arhiiv, Soome Kirjanduse Selts, Museovirasto) materjalid, mis on lähedased kõnesolevale kogule ja seotud sama uurimisteemaga, olen neid erineval täpsusastmel läbi töötanud üle 500. Sihipäraselt hakkasin selliseid teemajutustusi lugema ja uurima seoses perepärimuse ja eriti suguvõsaloo uurimisega 1990. aastate esimesel poolel. Elulugude ja pikemate kirjalike teemajutustustega olen järjepidevalt tegelenud 1997. aastast. Lisaks olen lugenud avaldatud materjale, millel toimetatuna on teine väärtus ja ehk ka tähendus kui käsikirjadel. Eelnev puudutab ainult käsikirju.

${ }^{4}$ Enne oma kooliaega ta aastaid ei maini, kuid kasutab teistlaadi ajamääratlust (Ikla kolhoosi aeg).

\section{Arhiiviallikad}

EKLA f 350 = Eesti Kultuurilooline Arhiiv, fond 350 (= Eesti elulood). 


\section{Kirjandus}

Arukask, Madis 2000. Eksimine vadja ja setu rahvakultuuris ning folkloorse etteantuse osa selles. Kõiva, Mare (toim). Sator: Artikleid usundi- ja kombeloost 2. Tartu: Eesti Kirjandusmuuseum, lk 96-112.

Bertaux, Daniel \& Bertaux-Wiame, Isabelle 1991. "Was du erlebst von deinen Vätern...": Transmission und soziale Mobilität über fünf Generationen. BIOS: Zeitschrift für Biographieforschung und Oral History 1, lk 13-40.

BIOS = BIOS: Zeitschrift für Biographieforschung und Oral History 1, 1991.

Honko, Lauri 1980. Miten luoda terminologia haltijaperinteen tutkimukselle? Kuusi, Matti \& Honko, Lauri \& Virtanen, Leea \& Pentikäinen, Juha. Perinteentutkimuksen perusteita. Porvoo \& Helsinki \& Juva: Werner Söderström Oy, lk 77-129.

Jackson, Michael 2002. The Politics of Strorytelling: Violence, Transgression and Intersubjectivity. Copenhagen: Museum Tusculanum Press.

Kidron, Carol A. 2003. Surviving a Distant Past: A Case Study of the Cultural Construction of Trauma Descendant Identity. Ethos: Journal of the Society for Psychological Anthropology 31: 4, lk 513-544.

Lotman, Juri 1991. Kultuurisemiootika: Tekst-kirjandus - kultuur. Tallinn: Olion.

Tulving, Endel 1994. Mälu. Tallinn: Kupar.

\section{Summary}

\section{Individual Choices and Socialisation as Reflected in Biographies}

Tiiu Jaago

Key words: biography, oral narrative history, social norms, Soviet period

The article observes the degree to which narrators of life stories interpret the course of their life as an individual choice and as a degree of inevitability resulting from the socio-historical context. Folkloristic approaches of the survival of the tradition as the intertwinement of predetermination (folklore awareness) and individual experience, and the approaches of the construction of "autobiographical self" based on the sciences of psychology in biographical research serve as the theoretical basis of the article. The material derives from three biographies sent to the Estonian Life Histories Association in the course of the collection competition of life histories conducted in 20002001 on the topic My life and the life of my family in Estonian SSR and the Republic of Estonia. The campaign resulted in over 300 life histories, currently held at the Archives of Cultural History of the Estonian Literary Museum (fund 350).

The main source of the article is a life history which is compared with two other stories from the angle of problem presentation. The first basis of comparison is the 
temporal context. The historical background of the stories of the informants, born in the early 1950s in rural communities in Estonia, has been shaped by the periods of stability under the Soviet regime: during 1950-1960 and during 1970-1980. The first period is described partly through hardships endured during the post-war period, and partly through the economic difficulties at the time collective farms were established. The second period is characterised as more stable, but was still marked with problems with shortage of goods. On the axis of individual course of life, the first period is associated with childhood and the role of family in the informants' lives, whereas the second period is associated with school, acquiring an occupation and the course of personal life. The second period also entails the formation of attitudes towards the Soviet theme.

The analysed life histories are presented in the context of events of the $1990 \mathrm{~s}$, the period of radical change in the political system of Estonia: how the narrators view the Soviet period now, at the time of independence, and how they perceive their opportunities in the new situation and which aspects do they see themselves as having been deprived of.

The second basis for comparison is the self-images of narrators in the extreme situations during the stable period of the Soviet Estonia (prison/army violence). The concordance between individual abilities and behavioural preferences point to the role of cultural predetermination in specific decisions of the individual.

The analysis of the narratives reflects the dynamics of predetermination and choices: historical-political framework as a predetermination, adaptation to it as a choice; origin as a predetermination, the interpretation of the life experience of one's family members as a choice; a violent situation as a predetermination, defiance with either physical force or analysis of experience is an individual choice, but also as a predetermination owing to personal qualities and abilities. The central analyses of personal histories diversify period analyses: the Soviet period in this case is not rendered meaningful only within the framework of the period (1940-1991) and political ideas. The issue of cultural continuity transgressing the limits of the period illustrate the life during and after the Soviet period. In the context of this article, the cultural continuity was expressed through the participation of family. 